\title{
A method for evaluating paleo hydrocarbon pools and predicting secondary reservoirs: a case study of the Sangonghe Formation in the Mosuowan area, Junggar Basin
}

\author{
Wei-Jiao $\mathrm{Ma}^{1,2} \cdot$ Yan-Zhao Wei ${ }^{2} \cdot$ Shi-Zhen Tao ${ }^{2}$
}

Received: 31 August 2017 / Published online: 26 April 2018

(c) The Author(s) 2018

\begin{abstract}
Taking the Jurassic Sangonghe Formation in the Mosuowan-Mobei area of the Junggar Basin as an example, this paper provides a method that evaluates paleo hydrocarbon pools and predicts secondary reservoirs. Through Quantitative Grain Fluorescence (QGF) experiments, well-tie seismic correlation, and paleo structure analysis, the scale and distribution of paleo hydrocarbon pools in the study area are outlined. Combining current structural features and fault characteristics, the re-migration pathways of paleo oil and gas are depicted. Based on barrier conditions on the oil re-migration pathways and current reservoir distribution, we recognize three types of secondary reservoirs. By analyzing structural evolution and sand body-fault distribution, the major control factors of secondary reservoirs are specified and, consequently, favorable zones for secondary reservoirs are predicted. The results are mainly as follows. (1) In the primary accumulation period in the Cretaceous, paleo hydrocarbon pools were formed in the Sangonghe Formation of the Mosuowan uplift and their size and distribution were extensive and the exploration potential for secondary reservoirs should not be ignored. Besides, paleo reservoirs were also formed in the Mobei uplift, but just small scale. (2) In the adjustment period in the Neogene, traps were reshaped or destroyed and so were the paleo reservoirs, resulting in oil release. The released oil migrated linearly northward along the structural highs of the Mobei uplift and the Qianshao low-relief uplift and then formed secondary reservoirs when it met new traps. In this process, a structural ridge cooperated with sand bodies and faults, applying unobstructed pathways for oil and gas re-migration. (3) The secondary hydrocarbon pools are classified into three types: low-relief anticlinal type, lithologic pinch-out type and fault block type. The distribution of the first type is controlled by a residual low uplift in the north flank of the paleo-anticline. The second type is distributed in the lithologic pinch-out zones on the periphery of the inherited paleo uplift. The third type is controlled by fault zones of which the strikes are perpendicular to the hydrocarbon re-migration pathways. (4) Four favorable zones for secondary reservoirs are predicted: the low-relief structural zone of the north flank of the Mosuowan paleo-anticline, the fault barrier zone on the western flank of the Mobei uplift, the Qianshao low-relief uplift and the north area of the Mobei uplift that parallels the fault zone. The study above effectively supports the exploration of the Qianshao low-relief uplift, with commercial oil discovered in the Qianshao1 well. Besides, the research process in this paper can also be applied to other basins to explore for secondary reservoirs.
\end{abstract}

Keywords Junggar Basin · Paleo hydrocarbon pools · Hydrocarbon re-migration pathways · Secondary reservoirs · Favorable zones

Edited by Jie Hao

Shi-Zhen Tao tsz@petrochina.com.cn
School of Earth and Space Sciences, Peking University, Beijing 100871, China

2 Research Institute of Petroleum Exploration and Development, Beijing 100083, China 


\section{Introduction}

With the continuous development of oilfield exploration, it becomes increasingly difficult, starting from the source rock, to find primary oil and gas pools, resulting in a stalemate in petroleum exploration. Meanwhile, secondary hydrocarbon pools are considered an important domain for high-efficiency reservoirs in recent years, because of their large exploration area, high quality, shallow burial depth and rapid productivity construction. In recent years, there have been significant breakthroughs in exploring for secondary oil and gas pools both at home and abroad, for example, the Middle-Upper Devonian (Frasnian) and Triassic petroleum system in the Midwest of the Ghdames Basin, North Africa (Underdown and Redfern 2008), multibillion barrel accumulation of heavy oil discovered in the Prudhoe Bay-Kuparuk area of the Arctic Alaska, North America (Bird and Houseknecht 2011), the Vuktyl oilfield in the Timan-Pechora Basin, Russia (IHS 2009), and the Upper Cretaceous Sarvak reservoir in the Azadengan oil field, southwest Iran (Du et al. 2016). In China, there also have been many discoveries, such as the Carboniferous and Triassic hydrocarbon pools in the Northern Tarim Basin (Zhu et al. 2013a, b), the Neogene oil and gas pools in the Bohai Bay and Qaidam Basins (Xu et al. 2016; Zhang et al. 2003; Li et al. 2015; Wang et al. 2015), the Jurassic natural gas in the Western Sichuan Foreland Basin (Ye et al. 2017), the industrial oil flow discovered in the Damoguaihe Formation in the Hailar Basin (Dong 2011), and the beadlike secondary oil and gas pools in the Heidimiao oil layer in the Songliao Basin (Huang and Guo 2014; Han et al. 2011).

Although secondary reservoirs can exhibit high productivity and high economic benefits, they are normally far from the source rocks, and the oil and gas are characterized by long distance migration in the lateral direction and cross-layer migration in the vertical direction. Besides, the reservoirs are commonly small in scale and widely dispersed as a result of damage, re-migration, and re-distribution from primary pools. The multi-stage hydrocarbon accumulation presents a challenge for further exploration. Much research has been conducted to elucidate the mechanism of secondary hydrocarbon migration and accumulation. For instance, aiming at the secondary reservoirs in the Jurassic-Cretaceous layer in the hinterland of the Junggar Basin, some accumulation rules have been raised such as distal secondary accumulation at a gentle slope ( $\mathrm{He}$ et al. 2004), fault-unconformity dominated migration and accumulation in fault-controlled sands in a low-relief structural trap (Hu et al. 2006), hydrocarbon migration along stair-like fractures and unconformity and accumulation outside the source (He et al. 2007), and facies-fault dominated distal hydrocarbon accumulation at a gentle slope (Tang et al. 2009). These models may provide an opportunity to analyze the hydrocarbon accumulation mechanism from one or two aspects; however, they are still unable to explain the accumulation rule from a dynamic process, which is supposed to start from the damage of paleo reservoirs to re-migration of oil and gas until reaccumulation of new hydrocarbon pools. Particularly, elaborate characterization of hydrocarbon migration and adjustment pathways and distribution rules of secondary reservoirs remain absent, resulting in no significant discovery for nearly 15 years since the two lithologic oil and gas pools, i.e., Shinan 21 and Shinan31 well blocks.

Secondary oil reservoirs are the result of adjustment of paleo ones. Therefore, identifying paleo oil pools and restoring their destruction and adjustment process are important for predicting favorable zones. At present, the analysis of paleo oil reservoirs is mainly based on the Grain containing Oil Inclusions method (GOI) (Wang et al. 2006; Cao et al. 2007) and Quantitative Grain Fluorescence technique (QGF) (Liu and Eadington 2005; Liu et al. 2007, 2013). GOI method identifies or measures oil inclusions on thin sections and, thus, drill cores are indispensable. Besides, the method is operated under microscope and is largely influenced by human factors. Compared to the GOI method, QGF technology can overcome the disadvantages of the limited drill cores, using cuttings to conduct single-well vertical and multi-well lateral comparison. In addition, the analysis parameters are obtained by machine, thus eliminating human factors and consuming less time. In recent years, this technique is applied more and more to the identification of paleo oil reservoirs. Formation of secondary reservoirs is generally after the damage of paleo ones. The common damages are the morphological change of traps caused by tectonic movements or the invalidation of the seals caused by faults (Tao et al. 2017; Wang et al. 2015; Zhu et al. 2013a, b). The reasons for the formation of secondary oil reservoirs have been deeply studied, while their prediction is rather lacking.

In this paper, based on an example of the Jurassic Sangonghe Formation in the Mosuowan-Mobei area in the hinterland of the Junggar Basin, we attempt to propose a systematic approach to evaluate paleo oil and gas pools and predict secondary ones. The approach started from paleo accumulations by defining their scale and distribution using quantitative grain fluorescence (QGF). Then, secondary exploration potential was evaluated. Next, the re-migration pathways were precisely depicted and dynamic adjustment processes were identified by analyzing structural features, fault systems and sand bodies. Then, the types of secondary hydrocarbon pools were classified; the main factors controlling their distribution were determined by considering 
trap conditions on the hydrocarbon adjustment pathways and present distribution features of reservoirs. Finally, favorable zones for secondary accumulations were proposed, providing valuable suggestions for the next-step exploration in the mid-shallow layer in the hinterland of the Junggar Basin. This systematic research can also be applied to other basins.

\section{Geological setting}

The Junggar Basin is a large superimposed petroliferous basin. It consists of six first-order tectonic units: the Wulungu Depression, Luliang Uplift, West Uplift, East Uplift, Central Depression and Northern Tianshan Piedmont Thrust Belt. Customarily, the vast central area is referred to as the hinterland, which mainly involves the first-order tectonic units of Luliang Uplift, Central Depression (the central part), and Wulungu Depression. The exploration area is about $40,000 \mathrm{~km}^{2}$ (Wei et al. 2014). Our study region includes two second-order tectonic units in the hinterland: the Mosuowan uplift and the Mobei uplift (Fig. 1). The oil and gas in the study area mainly existed in the Jurassic and Cretaceous. From the bottom to the top, the Jurassic strata consist of the Badaowan Formation $\left(\mathrm{J}_{1} \mathrm{~b}\right)$, Sangonghe Formation $\left(\mathrm{J}_{1} \mathrm{~s}\right)$; the Cretaceous strata consist of the Qingshuihe Formation $\left(\mathrm{K}_{1} \mathrm{q}\right)$, Hutubihe Formation $\left(\mathrm{K}_{1} \mathrm{~h}\right)$, Shengjinkou Formation $\left(\mathrm{K}_{1} \mathrm{~s}\right)$, Lianmuqin Formation $\left(\mathrm{K}_{2} \mathrm{l}\right)$ and Donggou Formation $\left(\mathrm{K}_{2} \mathrm{~d}\right)$. In this study, our targeted stratum is the Sangonghe Formation $\left(\mathrm{J}_{1} \mathrm{~s}\right)$, which is further divided into three members: the first member of the Sangonghe Formation $\left(\mathrm{J}_{1} \mathrm{~s}_{1}\right)$ in the bottom, the second member of the Sangonghe Formation $\left(\mathrm{J}_{1} \mathrm{~s}_{2}\right)$ in the middle, and the third member of the Sangonghe Formation $\left(\mathrm{J}_{1} \mathrm{~s}_{3}\right)$ in the top.

The hinterland was uplifted continually during the midlate Jurassic (Fig. 2), resulting in the development of the large-scale WSW-NE-trending Chepaizi-Mosuowan uplift in the Junggar Basin. The Mosuowan area is located in the main body of that uplift and is called Mosuowan paleo uplift. In the early Cretaceous, the paleo uplift subsided steadily, forming anticlinal traps that were favorable for hydrocarbon accumulation. At the same time, the source rocks of the Middle Permian lower Urho Formation $\left(\mathrm{P}_{2} \mathrm{~W}\right)$ located in the Pen1 well west sag were at their generation and expulsion peak, providing sufficient oil and gas for the anticlinal traps (He et al. 2008; Ji et al. 2010; Xiang et al. 2016; Zhang et al. 2010). Furthermore, the Yanshan movement was at an active stage, forming inherited normal faults above the Hercynian thrust faults, acting as a "highspeed elevator" for delivering oil and gas from the lower strata to the upper reservoirs. Paleo structure-source rocksfault systems were well matched temporally and spatially, contributing to the formation of the Mosuowan paleo oil and gas pools. Some scholars have provided evidence for the existence of paleo reservoirs at earlier studies using reservoir GOI method (Cao et al. 2007; Xie et al. 2007; Zou et al. 2008), fluorescence color and intensity analysis of organic fluid inclusion (Sun 2009), since the QGF technique was introduced (Liu and Eadington 2005; Liu et al. 2007) and successfully applied in many basins of China (Gong et al. 2007; Lu et al. 2012; Liu et al. 2013). In

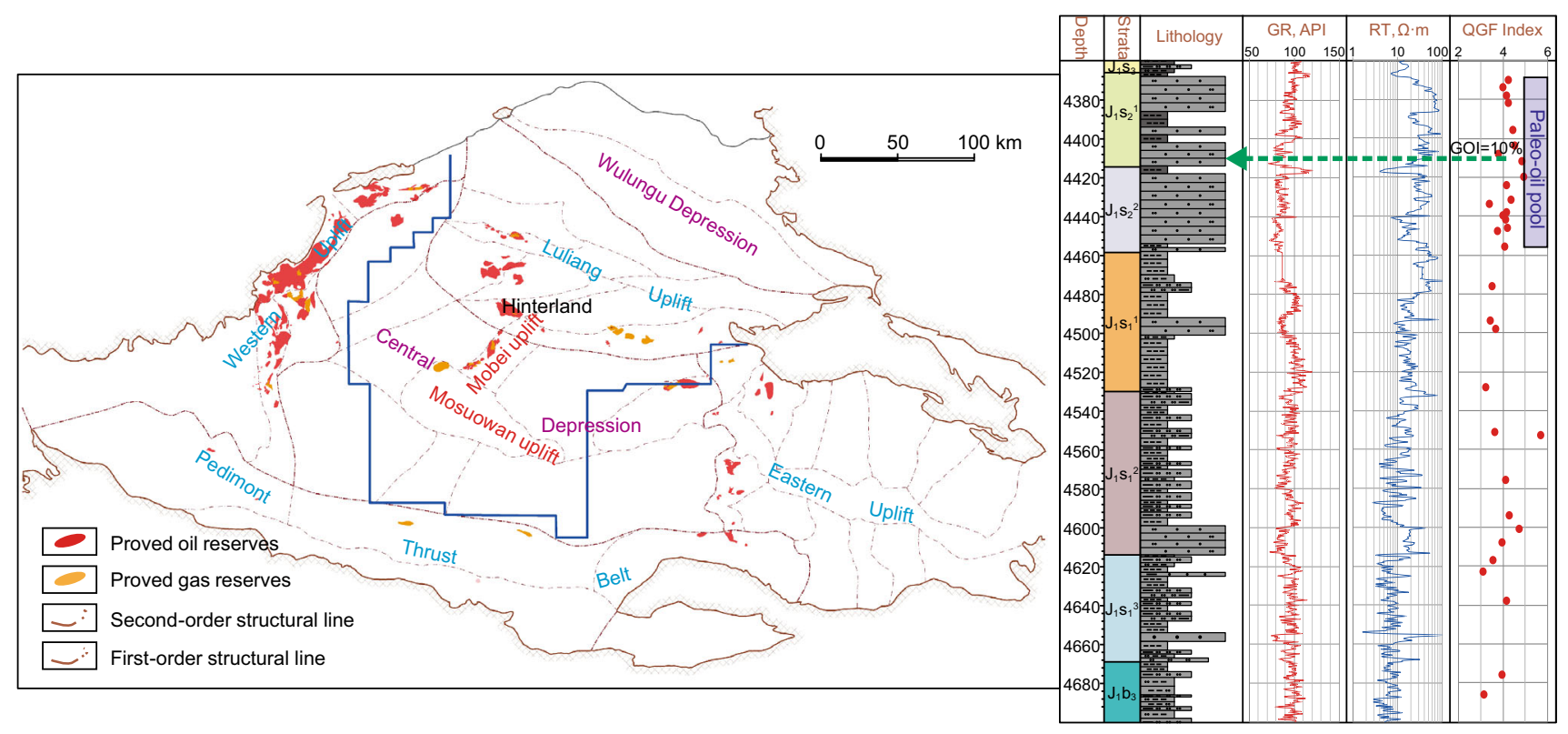

Fig. 1 Location of the study area, and stratigraphic column and change features of QGF index with depth of well MS1, the blue line circles the hinterland of the Junggar Basin (Modified after Ma et al. 2017) 


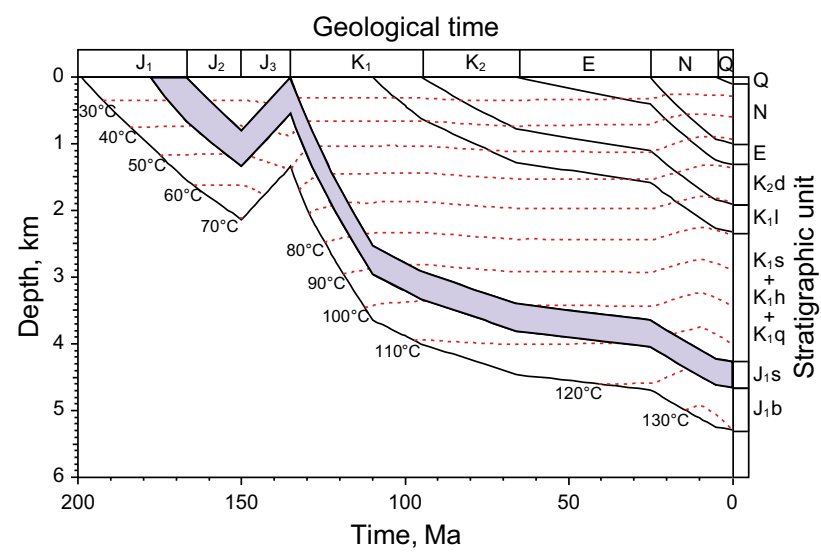

Fig. 2 Burial-thermal history of the Mosuowan uplift

recent years, we also applied the technique to the Junggar Basin in the previous study to determine the thickness of the paleo oil layer in the Mosuowan uplift and reconstruct its hydrocarbon charging history, through integrated analysis of single-well continuous QGF index and series inclusion analysis (Ma et al. 2016, 2017) (Fig. 1).

In the Neogene, the source rocks had passed the generation and expulsion peak and, thus, no longer supplied oil and gas to the Mosuowan paleo uplift. In the meantime, the intense activity of the Himalayan orogeny caused the southward tilting of the whole hinterland of the Junggar Basin. As a result, structures of the Jurassic strata and those above exhibited a monocline shape, representing a paleomorphological high in the north and morphological low in the south. The monocline strata not only damaged the existing traps, but also provided a force for the hydrocarbon re-migration. Subsequently, hydrocarbons spilled out from the paleo reservoirs and were either lost or re-accumulated in new traps to form new hydrocarbon pools known as secondary hydrocarbon pools.

\section{Distribution of paleo oil and gas pools}

\subsection{Samples and experiments}

The existence of paleo oil and gas pools in the $\mathrm{J}_{1} \mathrm{~s}$ in MS1 well block has been confirmed by single-well continuous QGF analysis (Ma et al. 2016, 2017). In this study, QGF experiment was conducted for another seven wells distributed on the Mosuowan-Mobei area to determine the scale and distribution of the paleo reservoirs. There are a total of 29 samples and sampling locations are shown in Fig. 3. Five core samples are from Well M3, with depth ranging from $4354.21 \mathrm{~m}$ to $4379.3 \mathrm{~m}$; five core samples are from Well M5, depth ranging from $4287 \mathrm{~m}$ to $4311.8 \mathrm{~m}$; 4 cutting samples are from Well M7, $4236 \mathrm{~m}$ to $4250 \mathrm{~m}$; five

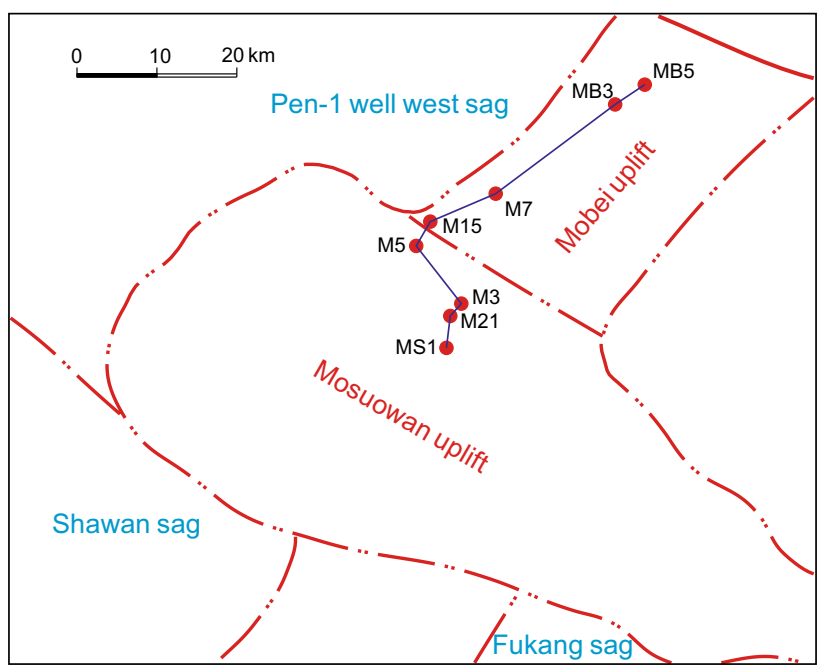

Fig. 3 Well distribution of quantitative grain fluorescence experiment

core samples are from Well M15, $4293.35 \mathrm{~m}$ to $4309.7 \mathrm{~m}$; five core samples from Well M21, $4358 \mathrm{~m}$ to $4396 \mathrm{~m}$; two core samples from Well MB3, $3803.95 \mathrm{~m}$ and $3808.1 \mathrm{~m}$; and three core samples from Well MB5, $3727.6 \mathrm{~m}$ to $3731 \mathrm{~m}$. These samples are mostly gray to green colored fine sandstone, with few moderate to fine sandstone, gravel-bearing sandstone and inequigranular sandstone. All the 29 samples were conducted QGF experiment.

The experimental procedure was as the following. The cutting samples were washed by hydrogen peroxide to remove the mud. The core and cutting samples were then crushed into single grains and then sieved to obtain grains with a $63 \mu \mathrm{m}-1 \mathrm{~mm}$ size distribution. Next, a mineral separation step was employed using magnetic separation machine to remove shale or coal fragments. Then, about $1 \mathrm{~g}-2 \mathrm{~g}$ grains were weighed and cleaned by dichloromethane, hydrochloric acid, and hydrogen peroxide to remove the clay minerals, carbonate cement, and free hydrocarbon on the surface of the reservoir grains. After that, the grains were dried. Next, dichloromethane was added to the dried samples to remove surface adsorbed hydrocarbon and then the samples were dried again for the QGF (Quantitative Grain Fluorescence) experiment to be conducted. The analysis was conducted on a Varian CaryEclipse fluorescence spectrophotometer in the Research Institute of Petroleum Exploration and Development, PetroChina. The results are listed in Table 1.

\subsection{Features of paleo structure and distribution of faults}

The earlier research has proved that the paleo hydrocarbon pools in the $\mathrm{J}_{1} \mathrm{~s}$ in the Mosuowan uplift were formed during Cretaceous (Ma et al. 2017). Thus, the Cretaceous paleo structure had significant control over primary hydrocarbon 
Table 1 Results of the quantitative grain fluorescence experiment

\begin{tabular}{|c|c|c|c|c|c|}
\hline Well name & Sample no. & Depth, m & Formation & Lithology & QGF index \\
\hline \multirow[t]{5}{*}{ M3 } & M3_1 & 4354.21 & $\mathrm{~J}_{1} \mathrm{~s}_{2}^{1}$ & Gray muddy siltstone & 16.5 \\
\hline & M3_2 & 4370.43 & $\mathrm{~J}_{1} \mathrm{~s}_{2}^{2}$ & Gray fine sandstone & 6.5 \\
\hline & M3_3 & 4372.85 & $\mathrm{~J}_{1} \mathrm{~s}_{2}^{2}$ & Gray fine sandstone & 15.8 \\
\hline & M3_4 & 4376 & $\mathrm{~J}_{1} \mathrm{~s}_{2}^{2}$ & Gray fine sandstone & 7.4 \\
\hline & M3_5 & 4379.3 & $\mathrm{~J}_{1} \mathrm{~s}_{2}^{2}$ & Gray fine sandstone & 24.4 \\
\hline \multirow[t]{5}{*}{ M5 } & M5_1 & 4287 & $\mathrm{~J}_{1} \mathrm{~s}_{2}^{1}$ & Gray fine sandstone & 7.8 \\
\hline & M5_2 & 4290.9 & $\mathrm{~J}_{1} \mathrm{~s}_{2}^{1}$ & Gray fine sandstone & 7.7 \\
\hline & M5_3 & 4294.25 & $\mathrm{~J}_{1} \mathrm{~s}_{2}^{1}$ & Gray fine sandstone & 8.0 \\
\hline & M5_4 & 4308.6 & $\mathrm{~J}_{1} \mathrm{~s}_{2}^{1}$ & Gray fine sandstone & 8.0 \\
\hline & M5_5 & 4311.8 & $\mathrm{~J}_{1} \mathrm{~s}_{2}^{2}$ & Gray fine sandstone & 7.0 \\
\hline \multirow[t]{4}{*}{ M7 } & M7_1 & 4236 & $\mathrm{~J}_{1} \mathrm{~s}_{2}^{2}$ & Gray fine sandstone & 18.8 \\
\hline & M7_2 & 4240 & $\mathrm{~J}_{1} \mathrm{~s}_{2}^{2}$ & Gray fine sandstone & 6.0 \\
\hline & M7_3 & 4244 & $\mathrm{~J}_{1} \mathrm{~s}_{2}^{2}$ & Gray fine sandstone & 7.3 \\
\hline & M7_4 & 4250 & $\mathrm{~J}_{1} \mathrm{~s}_{2}^{2}$ & Gray fine sandstone & 12.7 \\
\hline \multirow[t]{5}{*}{ M15 } & M15_1 & 4293.35 & $\mathrm{~J}_{1} \mathrm{~s}_{2}^{1}$ & Gray medium-fine sandstone & 9.7 \\
\hline & M15_2 & 4296.5 & $\mathrm{~J}_{1} \mathrm{~s}_{2}^{1}$ & Gray gravel-bearing sandstone & 7.7 \\
\hline & M15_3 & 4299 & $\mathrm{~J}_{1} \mathrm{~s}_{2}^{1}$ & Gray gravel-bearing sandstone & 9.5 \\
\hline & M15_4 & 4305.5 & $\mathrm{~J}_{1} \mathrm{~s}_{2}^{2}$ & Gray fine sandstone & 9.8 \\
\hline & M15_5 & 4309.7 & $\mathrm{~J}_{1} \mathrm{~s}_{2}^{2}$ & Gray fine sandstone & 4.1 \\
\hline \multirow[t]{5}{*}{ M21 } & M21_1 & 4358 & $\mathrm{~J}_{1} \mathrm{~s}_{2}^{1}$ & Gray fine sandstone & 10.6 \\
\hline & M21_2 & 4366 & $\mathrm{~J}_{1} \mathrm{~s}_{2}^{2}$ & Gray fine sandstone & 6.6 \\
\hline & M21_3 & 4376 & $\mathrm{~J}_{1} \mathrm{~s}_{2}^{2}$ & Gray fine sandstone & 11.3 \\
\hline & M21_4 & 4388 & $\mathrm{~J}_{1} \mathrm{~s}_{2}^{2}$ & Gray fine sandstone & 11.2 \\
\hline & M21_5 & 4396 & $\mathrm{~J}_{1} \mathrm{~s}_{2}^{2}$ & Gray fine sandstone & 6.1 \\
\hline \multirow[t]{2}{*}{ MB3 } & MB3_1 & 3803.95 & $\mathrm{~J}_{1} \mathrm{~s}_{2}^{2}$ & Green-gray fine sandstone & 7.3 \\
\hline & MB3_2 & 3808.1 & $\mathrm{~J}_{1} \mathrm{~s}_{2}^{2}$ & Green-gray fine sandstone & 7.1 \\
\hline \multirow[t]{3}{*}{ MB5 } & MB5_1 & 3727.6 & $\mathrm{~J}_{1} \mathrm{~s}_{2}^{2}$ & Green-gray inequigranular sandstone & 9.2 \\
\hline & MB5_2 & 3728.1 & $\mathrm{~J}_{1} \mathrm{~s}_{2}^{2}$ & Green-gray inequigranular sandstone & 13.7 \\
\hline & MB5_3 & 3731 & $\mathrm{~J}_{1} \mathrm{~s}_{2}^{2}$ & Green-gray inequigranular sandstone & 17.7 \\
\hline \multirow[t]{18}{*}{ MS1 } & MS1_1 & 4370 & $\mathrm{~J}_{1} \mathrm{~s}_{2}^{1}$ & Silty-fine sandstone & 4.3 \\
\hline & MS1_2 & 4374 & $\mathrm{~J}_{1} \mathrm{~s}_{2}^{1}$ & Silty-fine sandstone & 4.0 \\
\hline & MS1_3 & 4378 & $\mathrm{~J}_{1} \mathrm{~s}_{2}^{1}$ & Silty-fine sandstone & 4.2 \\
\hline & MS1_4 & 4382 & $\mathrm{~J}_{1} \mathrm{~s}_{2}^{1}$ & Silty-fine sandstone & 4.3 \\
\hline & MS1_5 & 4396 & $\mathrm{~J}_{1} \mathrm{~s}_{2}^{1}$ & Silty-fine sandstone & 4.5 \\
\hline & MS1_6 & 4404 & $\mathrm{~J}_{1} \mathrm{~s}_{2}^{1}$ & Silty-fine sandstone & 4.5 \\
\hline & MS1_7 & 4408 & $\mathrm{~J}_{1} \mathrm{~s}_{2}^{1}$ & Silty-fine sandstone & 3.8 \\
\hline & MS1_8 & 4412 & $\mathrm{~J}_{1} \mathrm{~s}_{2}^{1}$ & Silty-fine sandstone & 4.9 \\
\hline & MS1_9 & 4420 & $\mathrm{~J}_{1} \mathrm{~s}_{2}^{2}$ & Silty-fine sandstone & 4.9 \\
\hline & MS1_10 & 4424 & $\mathrm{~J}_{1} \mathrm{~s}_{2}^{2}$ & Silty-fine sandstone & 4.2 \\
\hline & MS1_11 & 4432 & $\mathrm{~J}_{1} \mathrm{~s}_{2}^{2}$ & Silty-fine sandstone & 4.4 \\
\hline & MS1_12 & 4434 & $\mathrm{~J}_{1} \mathrm{~s}_{2}^{2}$ & Silty-fine sandstone & 3.4 \\
\hline & MS1_13 & 4438 & $\mathrm{~J}_{1} \mathrm{~s}_{2}^{2}$ & Silty-fine sandstone & 4.2 \\
\hline & MS1_14 & 4440 & $\mathrm{~J}_{1} \mathrm{~s}_{2}^{2}$ & Silty-fine sandstone & 4.0 \\
\hline & MS1_15 & 4442 & $\mathrm{~J}_{1} \mathrm{~s}_{2}^{2}$ & Silty-fine sandstone & 4.1 \\
\hline & MS1_16 & 4446 & $\mathrm{~J}_{1} \mathrm{~s}_{2}^{2}$ & Silty-fine sandstone & 4.2 \\
\hline & MS1_17 & 4448 & $\mathrm{~J}_{1} \mathrm{~s}_{2}^{2}$ & Silty-fine sandstone & 3.8 \\
\hline & MS1_18 & 4456 & $\mathrm{~J}_{1} \mathrm{~s}_{2}^{2}$ & Silty-fine sandstone & 4.1 \\
\hline
\end{tabular}


accumulation. At the Early Cretaceous, a wide-spread lacustrine transgression occurred in the Junggar Basin, forming dark mudstone (the mudstone was characterized by high-Gamma on logging curves and thus called highGamma mudstone) that was steadily distributed and vertically overlaid on the Cretaceous basal conglomerate in the hinterland of the basin. Therefore, flattening the top surface of this high-Gamma mudstone allows us to analyze the structural feature of different target layers below it. Accordingly, the paleo structure map of the $\mathrm{J}_{1} \mathrm{~s}$ in the Early Cretaceous was restored (Fig. 4). The $\mathrm{J}_{1} \mathrm{~s}$ shows a clear paleo-anticline on the Mosuowan uplift during the Early Cretaceous, which is significantly different from the present-day anticline. The structural high is located in the southwest of Well MS1, in proximity to the Permian hydrocarbon-generating sag and, therefore, is considered a favorable area to accumulate oil and gas.

Figure 4 also shows the planar feature of the Jurassic Faults. The NE-trending faults are very common in the
Mobei uplift, distributed in en-échelon form. This kind of fault has a short lateral distance. By contrast, the NWtrending faults developed in the Mosuowan uplift exhibit relatively long distance laterally.

Combining well data and seismic data, the well-tie seismic section of MS1-M21-M3-M5-M15-M7-MB3-MB5 was calibrated to interpret horizons and faults. Then, the profile was flattened along the high-Gamma mudstone at the bottom of the second member of the Qingshuihe Formation $\left(K_{1} q_{2}\right)$, i.e., the bottom of the transgressive mudstone, to reflect the structural feature of the $J_{1}$ s during the Cretaceous (Fig. 5). It is shown by the section that faults developed in the Mosuowan uplift have relatively small throw, which have control only over the adjustment of shallow layer hydrocarbon pools and secondary accumulation, while those in the Mobei area have large vertical throw (some of which even extend to the deeply buried Hercynian faults) and connect to the source rock, e.g., the fault in close proximity to well MB3. These faults not only

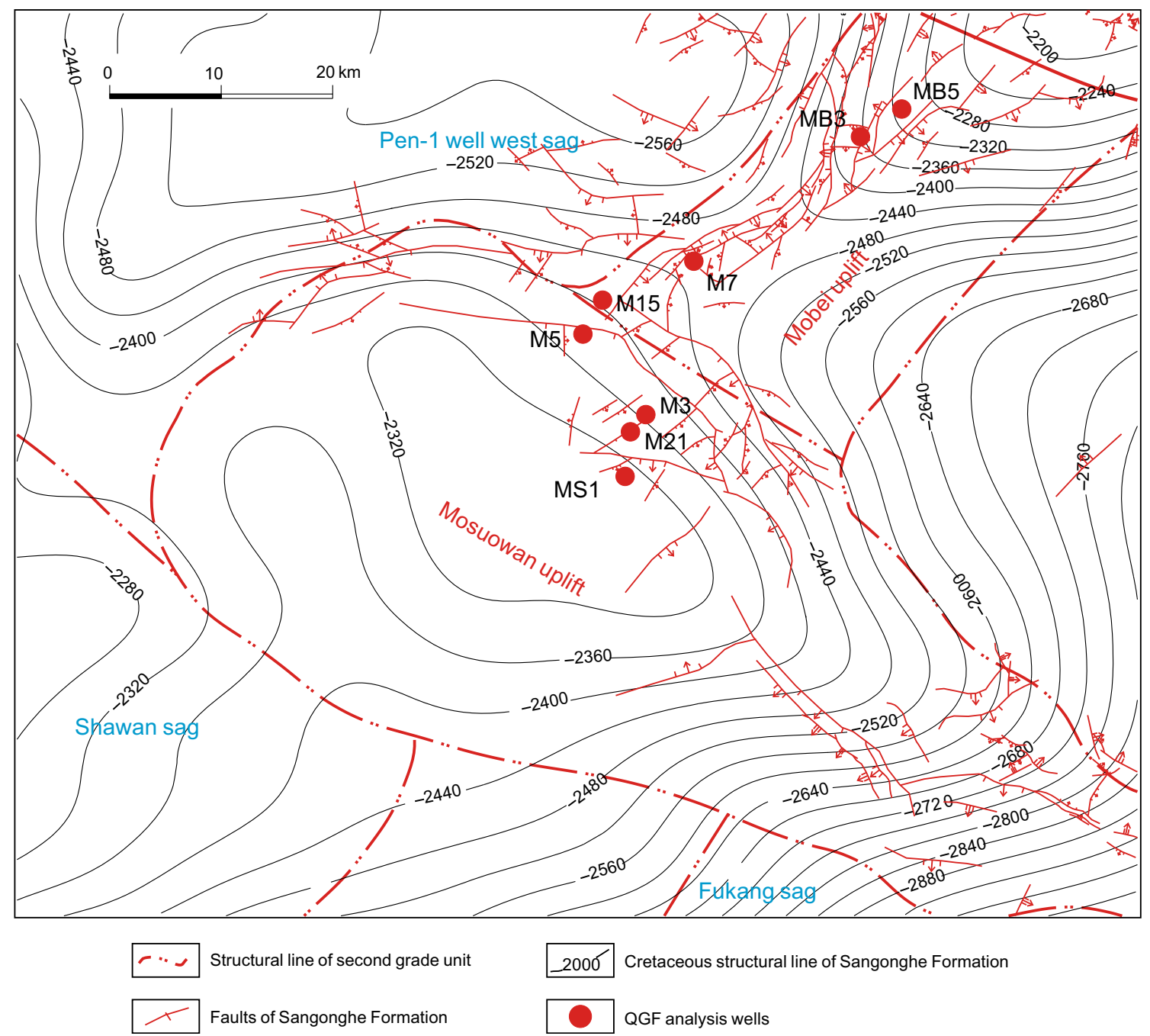

Fig. 4 Paleo structure of the Sangonghe Formation and distribution of Jurassic faults in the Cretaceous 


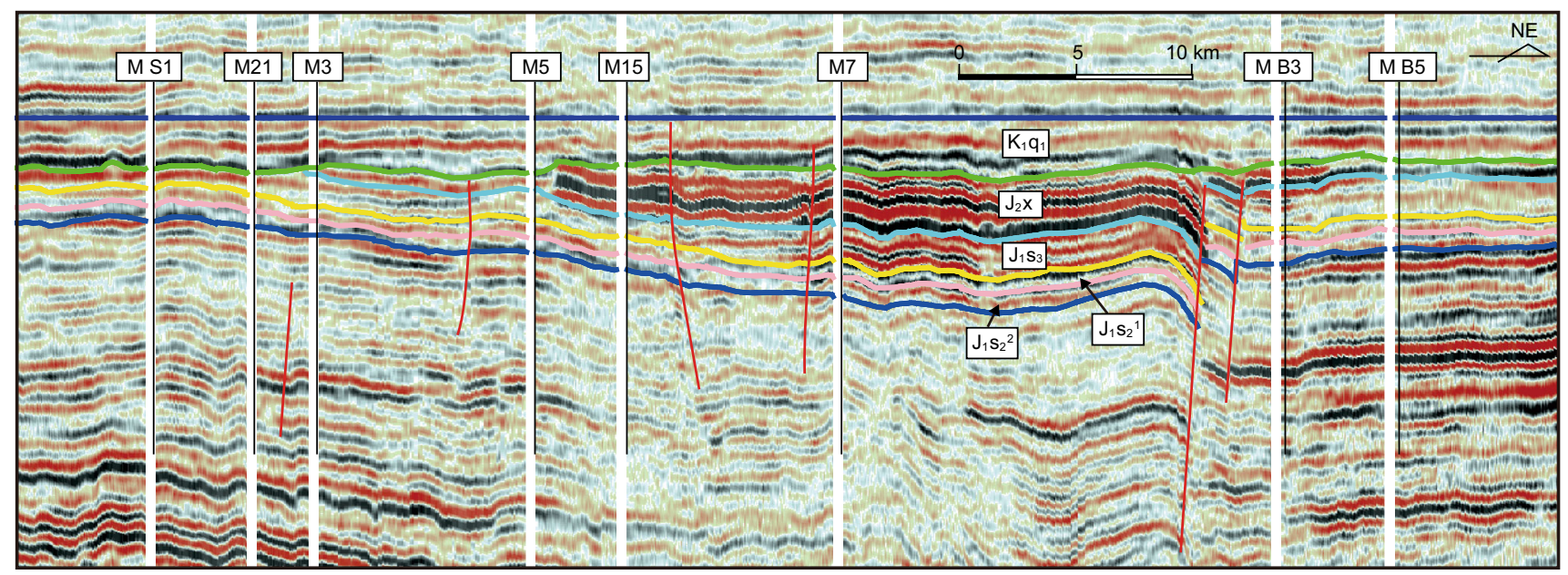

Fig. 5 Fault profile of the second member of the Sangonghe Formation in the Cretaceous (see location in Fig. 3)

provided vertical pathways for hydrocarbon migrating from the deep layers to the middle-shallow (Jurassic-Cretaceous) layers during the paleo accumulation period, but also acted as pathways and barriers for oil and gas re-accumulating during the adjustment stage.

\subsection{Distribution of sand bodies}

The Jurassic strata in the hinterland consists mainly of gentle slope and shallow-water sandstone sediments. Sand bodies of the $\mathrm{J}_{1} \mathrm{~s}_{2}$ were developed in a transgressive system tract. During the early stage of the transgressive system tract, sand types were mainly delta plain facies, with high sand-shale ratio and were greatly overlapped. Therefore, structural traps were easily developed while lithologic traps were absent. At the middle stage of the transgressive system tract, the water depth increased and sand-shale ratio decreased, so the reservoir type was dominated by deltaic front subaqueous distributary channel sand body, mouth bar sand body and lacustrine mudstone (Feng et al. 2015).

Sand body correlation across the MS1-M21-M3-M5M15-M7-MB3-MB5 wells is shown by Fig. 6. The first sand set of the second member of the Sangonghe Formation $\left(\mathrm{J}_{1} \mathrm{~s}_{2}^{1}\right)$ is a small-scale deltaic sand body with relatively low sand-shale ratio. They are less superimposed and, basically separated from each other, hence are highly likely to form lithologic traps. Instead, the second sand set $\left(\mathrm{J}_{1} \mathrm{~s}_{2}^{2}\right)$ is a large-scale deltaic sand body with relatively high sandshale ratio, with sand bodies connected with one another, overlapped, and hence are less likely to form lithologic traps. However, if those sand bodies met with faults or are located in an anticlinal structure, the opportunity for structural traps would be greatly increased. For example, the oil and gas pools formed in M7 well block are both controlled by anticlinal sand bodies and by faults. The scales of these structural traps are often larger than those lithologic ones formed by the first type of sand set.

\subsection{Scale and distribution of paleo oil and gas pools}

In combination with the sand body correlation, structural interpretation and newly experimented QGF index distribution (Fig. 7), the profile was mapped to restore the features of paleo hydrocarbon pools (Fig. 8).

The empirical value of QGF index for paleo oil pools is greater than 4. However, different areas have different standards in explaining the oil layer and water layer, for the reservoir characteristics may differ from each other. Therefore, the overall change trend of the QGF index in both vertical and horizontal direction should be considered (Liu and Eadington 2005). QGF index ranges from 6.6 to 11.3 in Well M21, averaging at 9.2; 6.5-24.4 in Well M3, averaging at $14.1 ; 7.7-8.0$ in Well M5, averaging at 7.7; 4.1-9.8 in Well M15, averaging at 8.1; 6.0-18.8 in Well M6, averaging at 11.2; and 9.2-17.7 in Well MB5, averaging at 13.6. Well MB3 has only two data points 7.1 and 7.3, respectively, averaging at 7.2. Starting from M7 and to the southwest towards well MS1, M21 well block shows greater QGF index than M5; in the northeast direction towards MB5, QGF index tends to increase. QGF index in M7 well block itself has exceeded 10. It is, therefore, inferred that MS1, M7 and MB5 well blocks accumulated large amount of hydrocarbon (Fig. 8). Hydrocarbon pools present in MS1 are anticline controlled, with oil layers' thickness of about $60 \mathrm{~m}$ (Fig. 1); those in M7 are fault- and anticline controlled, and in MB5 lithology controlled. From the section, we can see that the size of reservoirs of M7 and MB5 well blocks is much smaller than that of MS1 and the potential is not that large. 


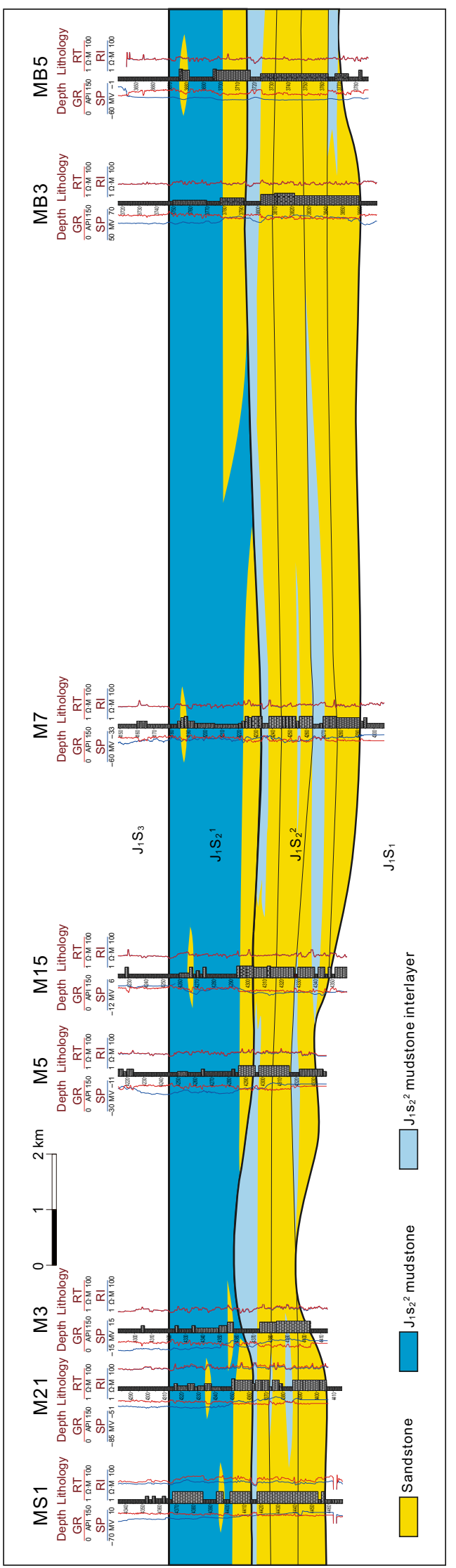

4Fig. 6 Sand body correlation of the second member of the Sangonghe Formation (see location in Fig. 3)

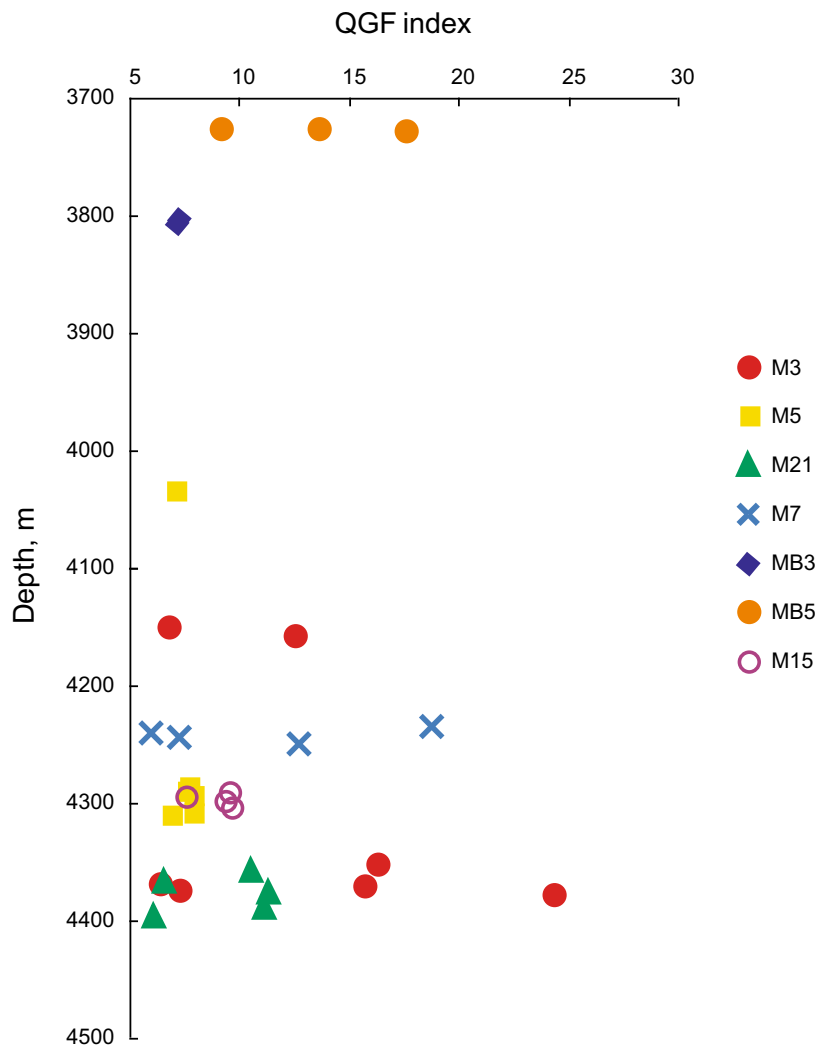

Fig. 7 QGF index trends of experimental wells

It should be noticed that well MS1 is located on a paleo structural high where hydrocarbons were supposed to be accumulated and, thus, should have a greater QGF index than M3 and M21. However, its QGF index ranges only from 3.4 to 4.9, as indicated by Table 1 and Fig. 1, which seems contradictory. This contradiction is due to reservoir quality over different well blocks. Samples from well MS1 are dominated by siltstone to fine sandstone. The practical size is rather small, with log-interpreted porosity ranging from $4.5 \%$ to $11.2 \%$, generally between $5.1 \%$ and $8.9 \%$, and shale content ranging from $3.0 \%$ to $28.4 \%$. They are, therefore, classified to be poor or even very poor quality reservoirs. However, samples from well M3 and M21 are composed of mainly fine sandstone, with log-interpreted porosity ranging from $9.2 \%$ to $14.1 \%$ and permeability from 0.21 to $30 \times 10^{-3} \mu \mathrm{m}^{2}$, and are classified to be moderate to good reservoirs (according to the Xinjiang oilfield internal report). Thus, these two kinds of reservoirs have different capacities in capturing inclusions during the paleo hydrocarbon charging process. This is possibly the reason why QGF index in well MS1 is relatively low compared to the other wells. 


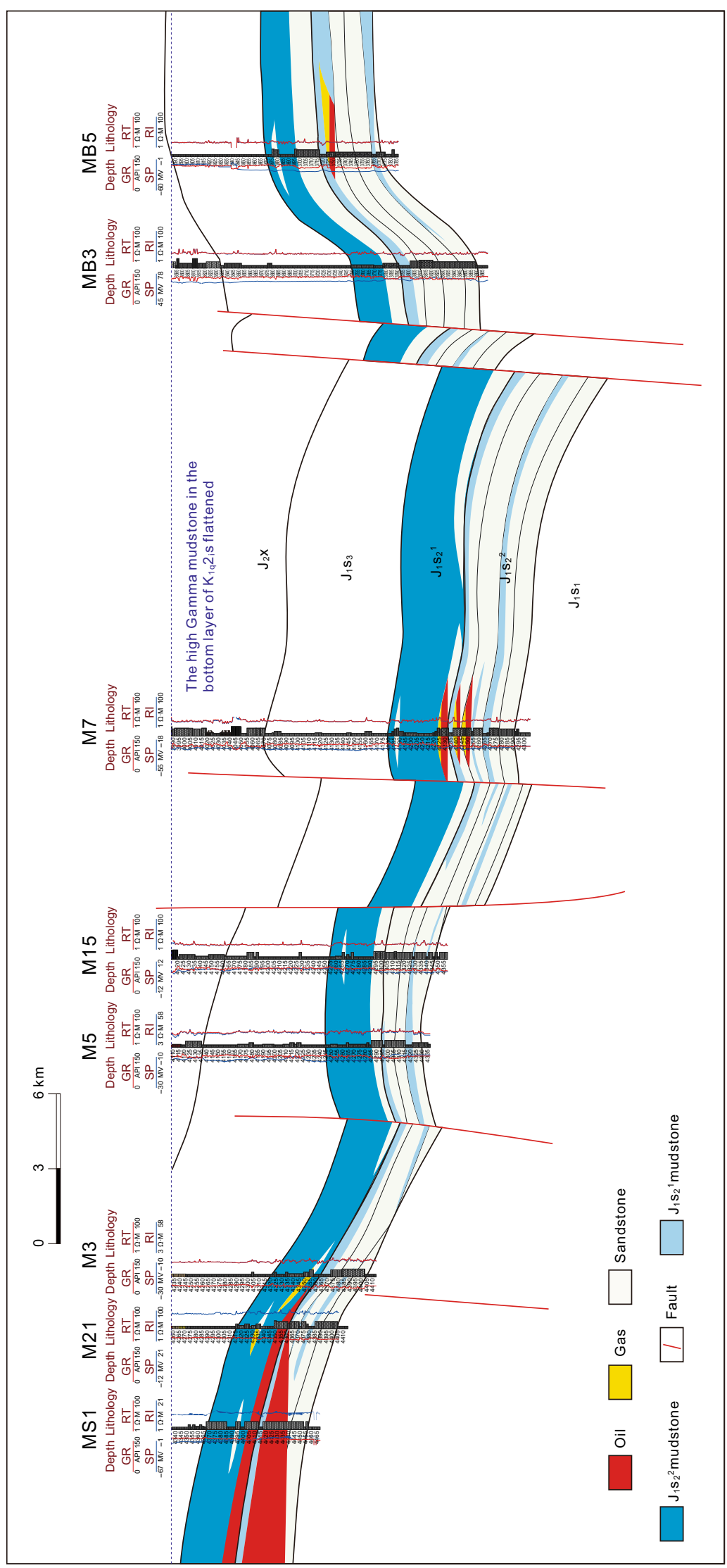

Fig. 8 Paleo reservoir distribution profile of the second member of the Sangonghe Formation (see location in Fig. 3) 
Projecting the profile distribution of paleo oil pools onto the planar structural map allows us to roughly circle the planar distribution and compute their plane area. Well M21 is situated right at the boundary of the paleo oil pool, indicating that the paleo structure was almost fully charged. If we define the areal extent of the paleo oil pool based on contour lines of the paleo-anticline along the Mosuowan uplift, the computed area is about $600 \mathrm{~km}^{2}$. The structural area of the paleo oil pool present in M7 and MB5 is relatively small (Fig. 9).

\section{Hydrocarbon re-migration pathway}

Paleo oil and gas pools, after being formed, tend to change with time. The occurrence of later tectonic activities may cause the trap to change in form or even be damaged, leading to release and re-migration of hydrocarbon. Accurate characterization of the hydrocarbon adjustment pathway is helpful for tracking the secondary oil and gas pools. This process requires the analysis of structural form during the adjustment period.

\subsection{Features of present structure and hydrocarbon distribution}

Influenced by the Himalayan movement, large-scale strata tilting of the Junggar Basin occurred during the Neogene. As a result, the preexisting structures shrank or even vanished. The Jurassic structure in the hinterland of the basin shows a monocline shape that is high in north and low in south. Many nose-like low uplift belts were developed under the monocline background. Structural map of the present-day hinterland (Fig. 10) indicates that the

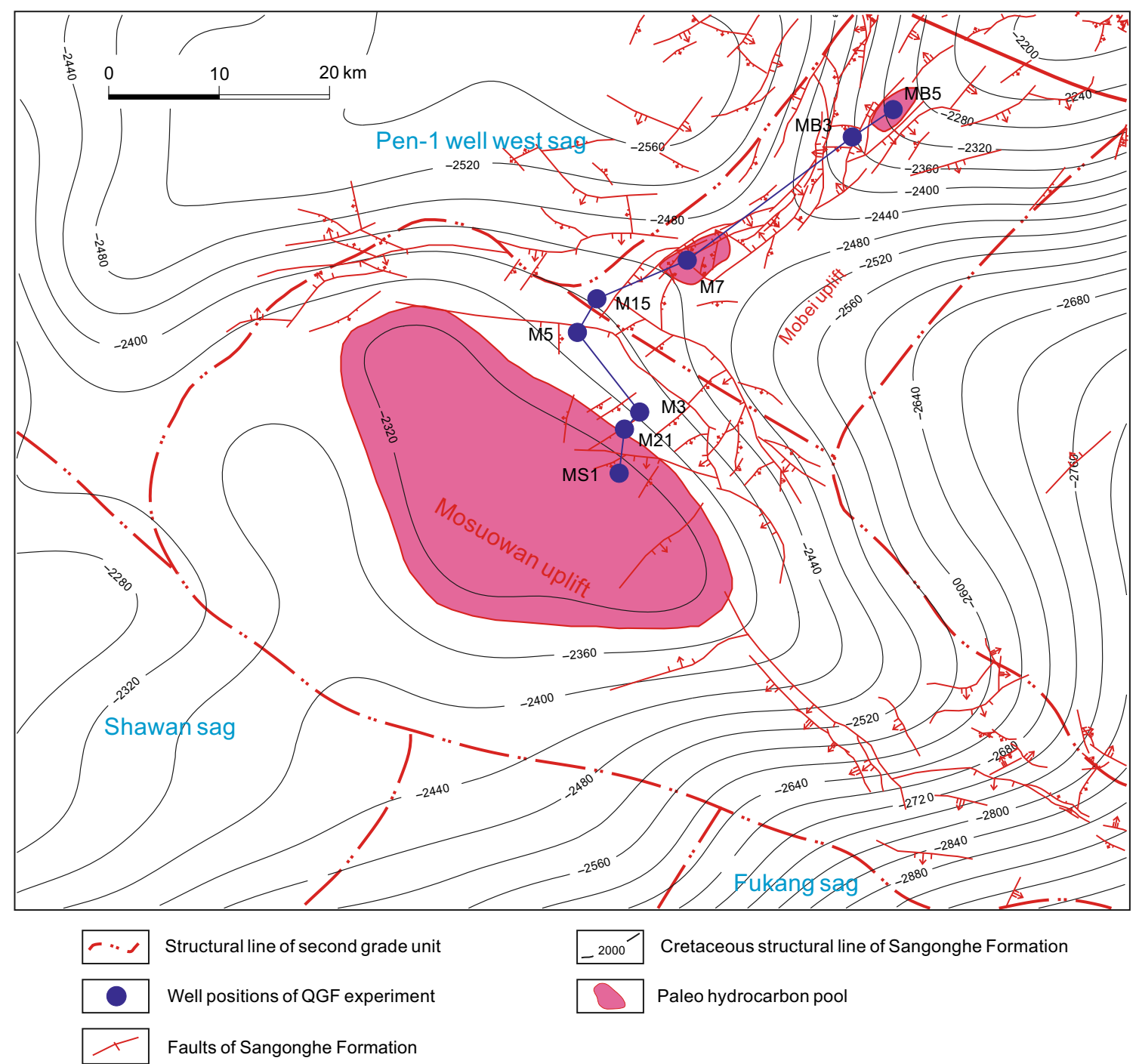

Fig. 9 Planar distribution of the paleo oil and gas pools 


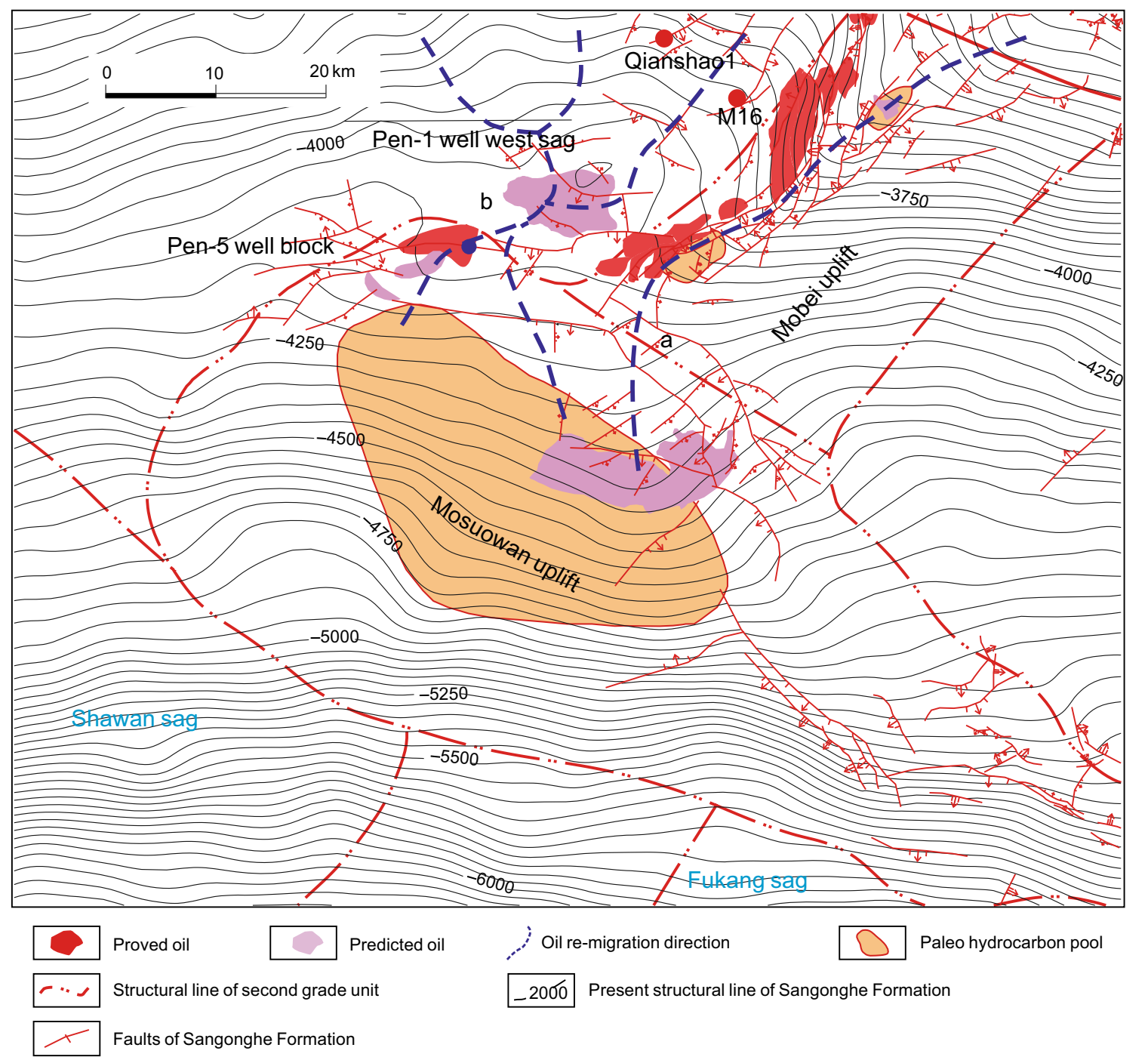

Fig. 10 Current structural features, oil distribution and predicted oil adjustment pathways. $a$ Migration direction in Mobei uplift, $b$ Migration direction of Qianshao low-relief uplift

Mosuowan paleo-anticline was damaged, with the southern flank becoming a monocline and the northern flank developing into an inherited residual low uplift. The Mobei uplift shows an inherited nose-like uplift belt both at the primary accumulation time and adjustment time. As for the faults, the Jurassic faults in the Mosuowan-Mobei area were formed and active during the Yanshanian Movement. The Himalayan faults were mainly active in the north area in the hinterland of the Junggar Basin (the Luliang uplift and Shixi uplift) and faulted out the Cretaceous and the above strata, few faults were formed in the MosuowanMobei area. So the planar faults characteristics in the study area only changed slightly.

The Mosuowan uplift differs greatly from the Mobei uplift in number, type and feature of discovered oil and gas pools. Figure 10 shows that the distribution feature of the current hydrocarbon pools is significantly different from that of the paleo ones. Primary reservoirs formed on paleo structural high were damaged; oil and gas re-migrated towards the north along the nose-like uplift belt and then re-accumulated in traps around the nose-like uplift belt. Large-scale oil pools were absent from the former area of the Mosuowan paleo reservoir and were replaced by the predicted reserves that are located at the northeastern flank of the paleo uplift, the Pen-5 well block and the Qianshao low-relief uplift belt. As for the Mobei uplift, current reservoirs are distributed in the northwestern part of the fault zone.

\subsection{Hydrocarbon re-migration pathways}

Hydrocarbon tends to migrate and accumulate towards the structural high. The structural ridge, as a height position, is undoubtedly the predominant migration pathway for oil 
and gas adjusting. However, it is only a general trend for hydrocarbon migration. Whether the structural ridge can be the predominant migration pathway is dependent not only on lateral variation of sand bodies (configuration of sand bodies and structural ridge), but also on cooperation between sand bodies and faults. According to fault characteristics (Fig. 5) and sand body distribution features (Fig. 6), the Jurassic faults and the sand bodies of the $J_{1} s$ are steadily distributed along the structural ridge, providing a favorable pathway for hydrocarbon adjustment. In addition, the present-day structural form and the oil and gas pools distribution indicate that hydrocarbon did migrate laterally and vertically along the structural ridge, through the thick sand bodies $\mathrm{J}_{1} \mathrm{~s}_{2}$ and the Jurassic faults. Although the structural ridges are the present day ones, they can reflect the general oil migration trend, for oil has been still at the adjustment period since the Himalayan movement.

Phenanthrene compounds have been widely used as a maturity indicator. For $R_{\mathrm{o}}<1.5 \%$, there is a linear correlation between phenanthrene index and maturity (Radke et al. 1986; Boreham et al. 1988). In the research, methylphenanthrene indices of the Jurassic reservoirs in the Mobei area were collected and analyzed. The distribution map shows that there is a trend of the methylphenanthrene index decreasing from south to north, indicating oil and gas migrating from the south towards the north. The migration paths are close to the structural ridge (Fig. 11).

Accordingly, two major hydrocarbon adjustment pathways along the structural ridge are predicted based on the present-day structural line: i.e., the structural ridge of the Mobei low uplift belt (a in Fig. 10) and the Qianshao lowrelief uplift belt (b in Fig. 10).

\section{Types and distribution rules of secondary oil and gas pools}

Released oil and gas would re-accumulate when met with appropriate barriers. If we analyze the barrier conditions on the hydrocarbon adjustment pathways and types and control factors of later-developed oil and gas pools, the factors that control the re-accumulation can be defined. After that, combined with the characteristics of the current structure, secondary reservoirs can be further predicted.

\subsection{Types of secondary oil and gas pools}

Through well-testing data (Table 2), sand body correlation and fault characteristics, the present oil pool profile was mapped (Fig. 12). The profile shows that the present-day hydrocarbon accumulation is controlled by both distribution of paleo oil and gas pools and the re-migration of oil and gas. The $\mathrm{J}_{1} \mathrm{~s}_{2}^{2}$ paleo oil pool that was originally located to the south of well MS1 had moved towards the north, forming a low-relief anticlinal oil pool, with its top located in the proximity of well M21. The $\mathrm{J}_{1} \mathrm{~s}_{2}^{1}$ gas pool was lithology controlled and was not influenced by strata tilting and, thus, it is preserved so far. Although there was no paleo oil and gas pools in the M15 well block at the Early Cretaceous, a commercial oil layer has been confirmed by well testing. It is, therefore, presumed that hydrocarbon accumulated in this layer was the result of later-stage adjustment. The $\mathrm{J}_{1} \mathrm{~s}_{2}^{1}$ gas-water layer in the M7 well block is classified as the lithologic pinch-out type, while the $\mathrm{J}_{1} \mathrm{~s}_{2}^{2}$ is controlled both by the structural high and a fault (there is no fault depicted in the profile, since the location of the profile is almost parallel to the fault strike). Well MB5 shares a similar commercial gas layer in $\mathrm{J}_{1} \mathrm{~s}_{2}^{1}$ with $\mathrm{M} 7$, which is also classified as a lithologic pinch-out type.

\subsection{Distribution of secondary oil and gas pools}

Secondary accumulations that were formed after the adjustment of the paleo oil and gas pools can be divided into three types, depending on their structural type and distribution characteristic in profile (Fig. 12): the first type is the low-relief anticlinal oil and gas pools, which are distributed mainly in the northern flank of the paleo-anticline, such as the M21 oil pool; the second type is the lithologic pinch-out oil and gas pools, which are distributed mainly in the lithologic pinch-out belt surrounding the inherited paleo uplift, such as the MB5 oil and gas pool and the M7 $\mathrm{J}_{1} \mathrm{~s}_{2}^{2}$ oil and gas pool; and the third type is the fault block oil and gas pools, which are distributed mainly in the fault zone whose strike is perpendicular to the adjustment or re-migration pathways, such as the M15 oil and gas pool and the M7 $\mathrm{J}_{1} \mathrm{~s}_{2}^{2}$ oil and gas pool. The followings are their formation mechanisms.

1. Residual low uplift belt on northern flank of paleoanticline.

Low-relief plays were developed on the northern flank of the anticline, which refers to the structural shape that was in the form of anticline at the primary hydrocarbon accumulation period which then turned into a low-relief structure as the result of strata tilting. Its formation process can be summarized as follows: in the strata tilting period also known as the adjustment period, the relief of the paleo-anticline reduced sharply, and the anticlinal top moved towards north or even vanished; thus in the northern flank of the former anticline (the present-day gentle structural zone), low-relief structures, i.e., residual low uplift, remained; those low-relief structures trapped the northward adjusting oil and gas to form new reservoirs. The oil and gas pool in the M21 well block is such an 


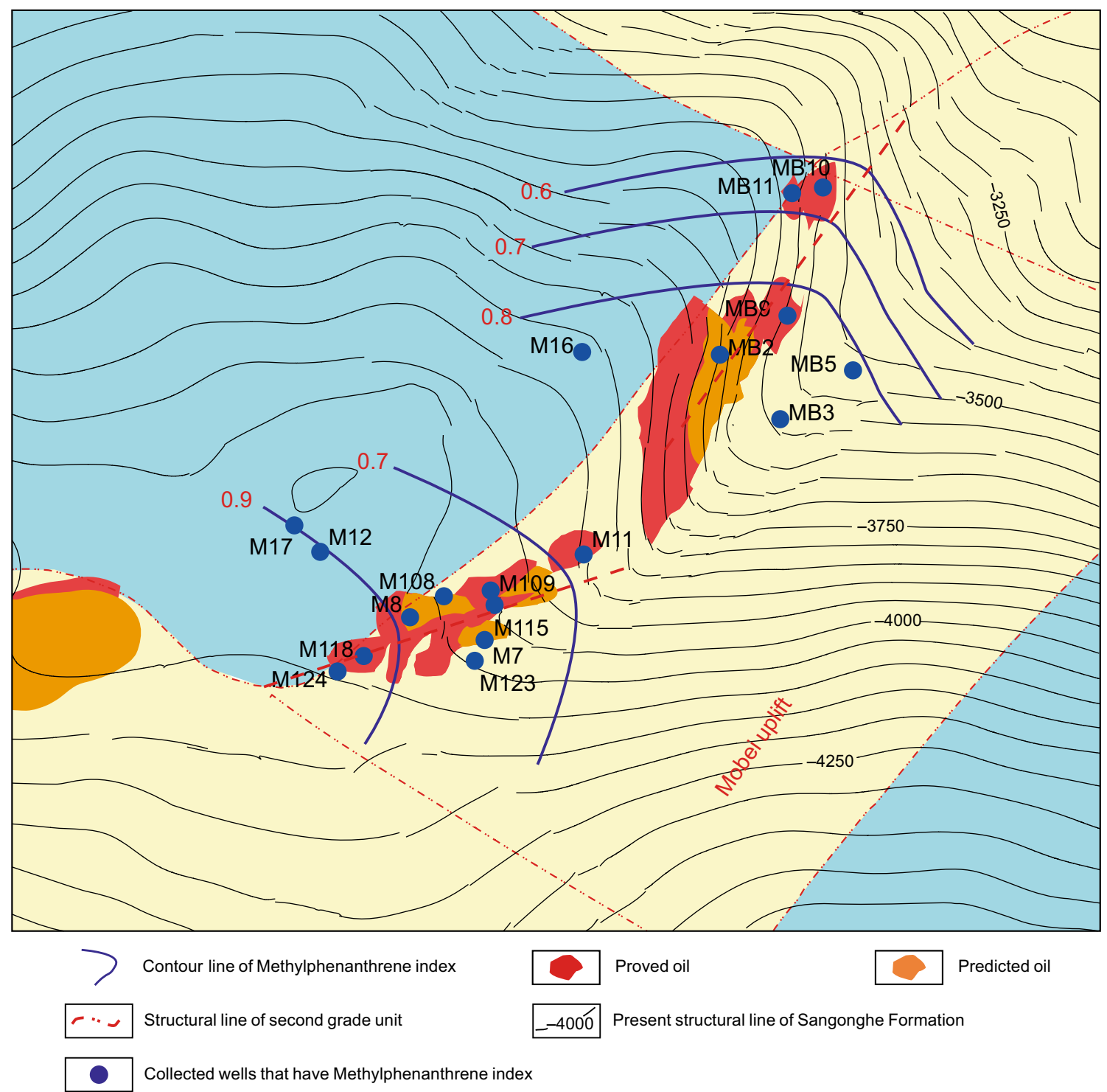

Fig. 11 Methylphenanthrene index showing migration direction

example. In the process above, the continuously distributed sand bodies in paleo structures are the key factors that control the hydrocarbon migration, while the presence of the low-relief anticline, the Yanshanian faults and sand bodies are the key factors that control the hydrocarbon accumulation. Oil and gas pools formed by this mechanism are classified as low-relief anticlinal type.

2. Lithologic pinch-out belt on the periphery of the inherited paleo uplift.

Some uplifts were inherited paleo uplifts from the primary accumulation period, which turned into monoclines in the tectonic tilting period. However, the lithologic reservoirs remained undamaged. Their formation process can be summarized as follows: the paleo uplifts often controlled the depositional system and strata denudation, leading to the formation of a denudation zone or lithologic pinch-out zone in its periphery areas; when the strata tilted, lithologic and stratigraphic traps tended to form on the northern flank of the uplift, so hydrocarbon migrating towards the north might be trapped to form lithologic and stratigraphic oil and gas pools. Some typical examples including the MB5 oil and gas pool and the M7 $\mathrm{J}_{1} \mathrm{~s}_{2}^{1}$ oil and gas pool are of this type. The presence of the Hercynian and Yanshanian faults and continuously distributed sand bodies are key factors that control the migration. The presence of the bay-shaped pinch-out line is a key factor that controls the accumulation.

3. Fault zone perpendicular to the migration pathway.

When the northward migrating oil and gas encountered the Yanshanian faults where the hanging wall happened to 
Table 2 Oil test result of the wells in profile

\begin{tabular}{|c|c|c|c|c|c|c|c|}
\hline $\begin{array}{l}\text { Well } \\
\text { name }\end{array}$ & $\begin{array}{l}\text { Top depth, } \\
\mathrm{m}\end{array}$ & $\begin{array}{l}\text { Bottom depth, } \\
\mathrm{m}\end{array}$ & $\begin{array}{l}\text { Thickness, } \\
\mathrm{m}\end{array}$ & $\begin{array}{l}\text { Daily oil output, } \\
\text { t/day }\end{array}$ & $\begin{array}{l}\text { Daily gas output, } \\
\mathrm{m}^{3} / \text { day }\end{array}$ & $\begin{array}{l}\text { Daily water output, } \\
\text { t/day }\end{array}$ & Oil test conclusion \\
\hline \multirow[t]{3}{*}{ M3 } & 4373 & 4403 & 24 & 1.18 & 0.07 & 6.37 & $\begin{array}{l}\text { Oil-bearing water } \\
\text { layer }\end{array}$ \\
\hline & 4355 & 4359 & 4 & - & 0.64 & 3.4 & $\begin{array}{l}\text { Gas-bearing water } \\
\text { layer }\end{array}$ \\
\hline & 4421.41 & 4499.75 & 78.34 & - & 0.135 & - & Gas-bearing layer \\
\hline \multirow[t]{2}{*}{ M5 } & 4300 & 4308 & 8 & 2.54 & - & 17.08 & $\begin{array}{l}\text { Oil-bearing water } \\
\text { layer }\end{array}$ \\
\hline & 4286 & 4294 & 8 & 0.25 & - & 25.26 & $\begin{array}{l}\text { Oil-bearing water } \\
\text { layer }\end{array}$ \\
\hline \multirow[t]{3}{*}{ M7 } & 4258 & 4262 & 4 & 15.94 & 11.782 & 19.86 & Gas-water layer \\
\hline & 4251.5 & 4253 & 1.5 & 11.39 & 6.042 & 8.23 & Gas-water layer \\
\hline & 4223 & 4232 & 9 & 11.92 & 6.99 & 5.98 & Gas-water layer \\
\hline \multirow[t]{2}{*}{ M15 } & 4443 & 4445 & 2 & - & - & - & Dry layer \\
\hline & 4296 & 4301 & 5 & 5.48 & - & 17.2 & Oil-water layer \\
\hline \multirow[t]{3}{*}{ M21 } & 5115 & 5130 & 15 & 8.3 & 1.107 & 14.64 & $\begin{array}{l}\text { Oil-bearing water } \\
\text { layer }\end{array}$ \\
\hline & 4470.12 & 4563.3 & 93.18 & 0.09 & 2.346 & 4.12 & Gas-water layer \\
\hline & 4351 & 4369 & 16 & 11.39 & 0.943 & 13.08 & Oil-water layer \\
\hline MB3 & 3805.2 & 3806.6 & 1.4 & 6.33 & - & 25.8 & Oil-water layer \\
\hline \multirow[t]{3}{*}{ MB5 } & 3723.72 & 3729.4 & 5.68 & 17.89 & 2.1 & - & Oil-gas layer \\
\hline & 3725 & 3732 & 7 & 12.6 & 1.53 & 22.18 & Oil-water layer \\
\hline & 3700 & 3716 & 14 & - & - & 23.3 & Water layer \\
\hline
\end{tabular}

be sandstone and footwall happened to be mudstone, they would no longer migrate but accumulate along a series of faults to form oil and gas pools that were vertically overlapped. The presence of the Yanshanian faults and connected sand bodies are key factors that control the hydrocarbon migration and accumulation.

\section{Prediction of favorable plays}

After the analysis of the hydrocarbon accumulation and distribution rules of the present-day oil and gas pools, four favorable zones of three types of secondary oil and gas plays are predicted on the basis of the present-day structural features (Fig. 13). The first type is the low-relief anticlinal type, distributed in the residual low uplift structural zone on the northern flank of the Mosuowan paleo uplift (I in the Fig. 13), which has migrated slightly northward compared with the paleo-anticline during the primary accumulation stage. The second type is the lithologic pinch-out type, distributed in the Qianshao low-relief uplift belt and the northern area of the Mobei uplift that parallels the fault zone (II and IV in the Fig. 13). These two areas have few faults and were structurally located in peripheral areas of the paleo uplift at the depositional stage, so they are considered favorable plays for lithologic reservoirs. The third type is the fault block type, distributed in the fault barrier zone on the western flank of the Mobei uplift (III in the Fig. 13), which has a nose-like uplift and is fully developed with faults.

At present, commercial oil has been found in well Qianshao1 in the Qianshao low-relief uplift belt and low productivity oil has been found in well M16. In addition, another three wells (F8, F9 and F10) were deployed surrounding these two oil wells to test the target layer, i.e., the Sangonghe Formation.

The Mosuowan paleo oil play exhibits significantly potential for secondary exploration after the hydrocarbon release, given its large-scale. However, there have been limited discoveries in the predicted zones so far. Thus, a detailed study on the hydrocarbon migration pathways and barrier conditions and fine characterization of paleo structures that existed during the hydrocarbon accumulation and adjustment periods are necessary. In addition, detailed research on fault-conformity-sand body migration systems is required for predicting the location of secondary oil and gas reservoirs. 


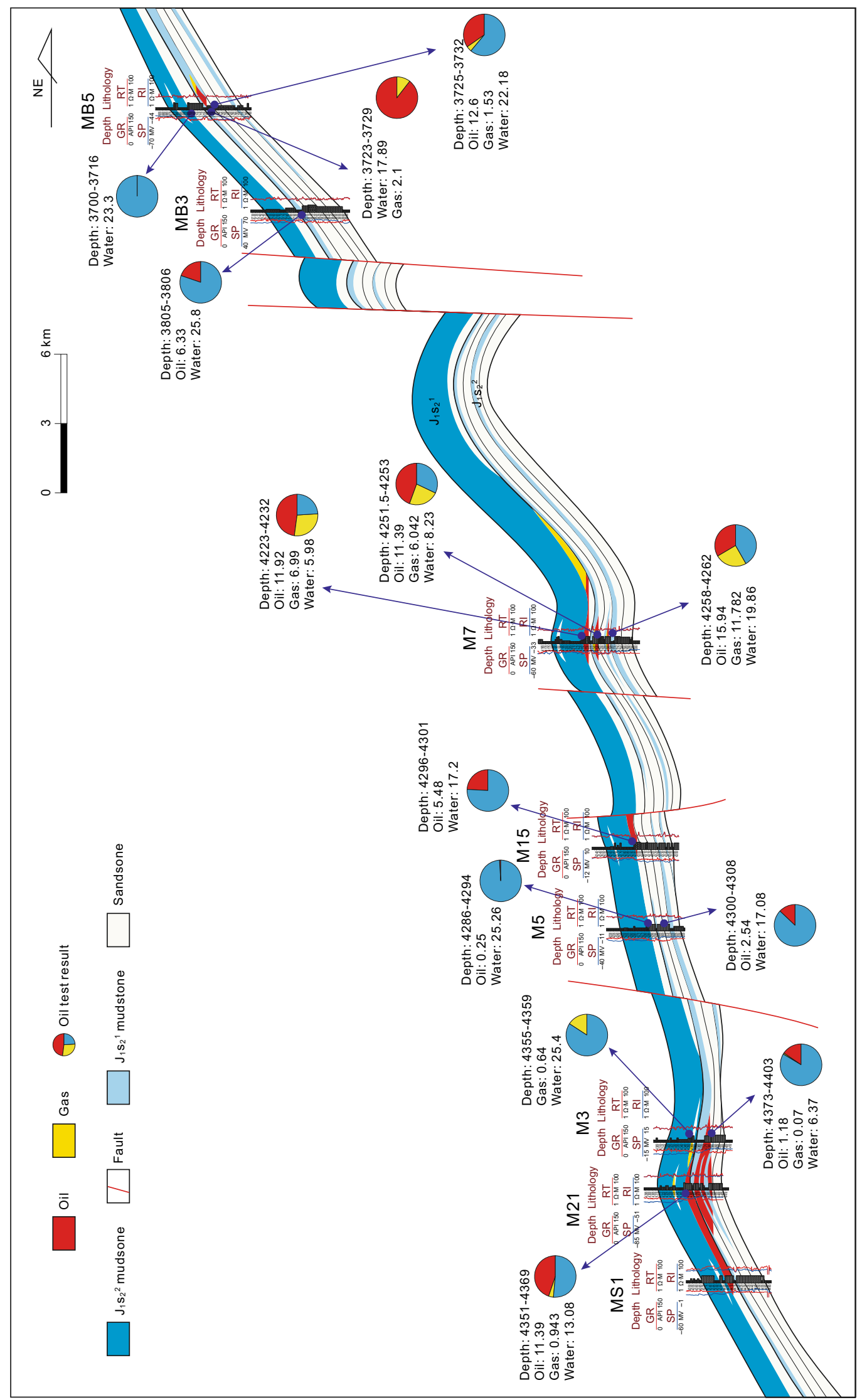


4Fig. 12 Profile of current reservoir distribution (see location in Fig. 3). In oil test pie charts, red color represents oil, which is measured in tonnes per day; blue color stands for water, which is measured in tonnes per day; yellow color is gas, which is measured in cubic meters per day hydrocarbon towards the north along the Mobei low uplift belt and the Qiaoshao low-relief uplift belt. As a result, secondary oil and gas pools were formed in reshaped traps or new traps. Different types of oil and gas pools were formed along the adjustment pathways after the paleo ones,

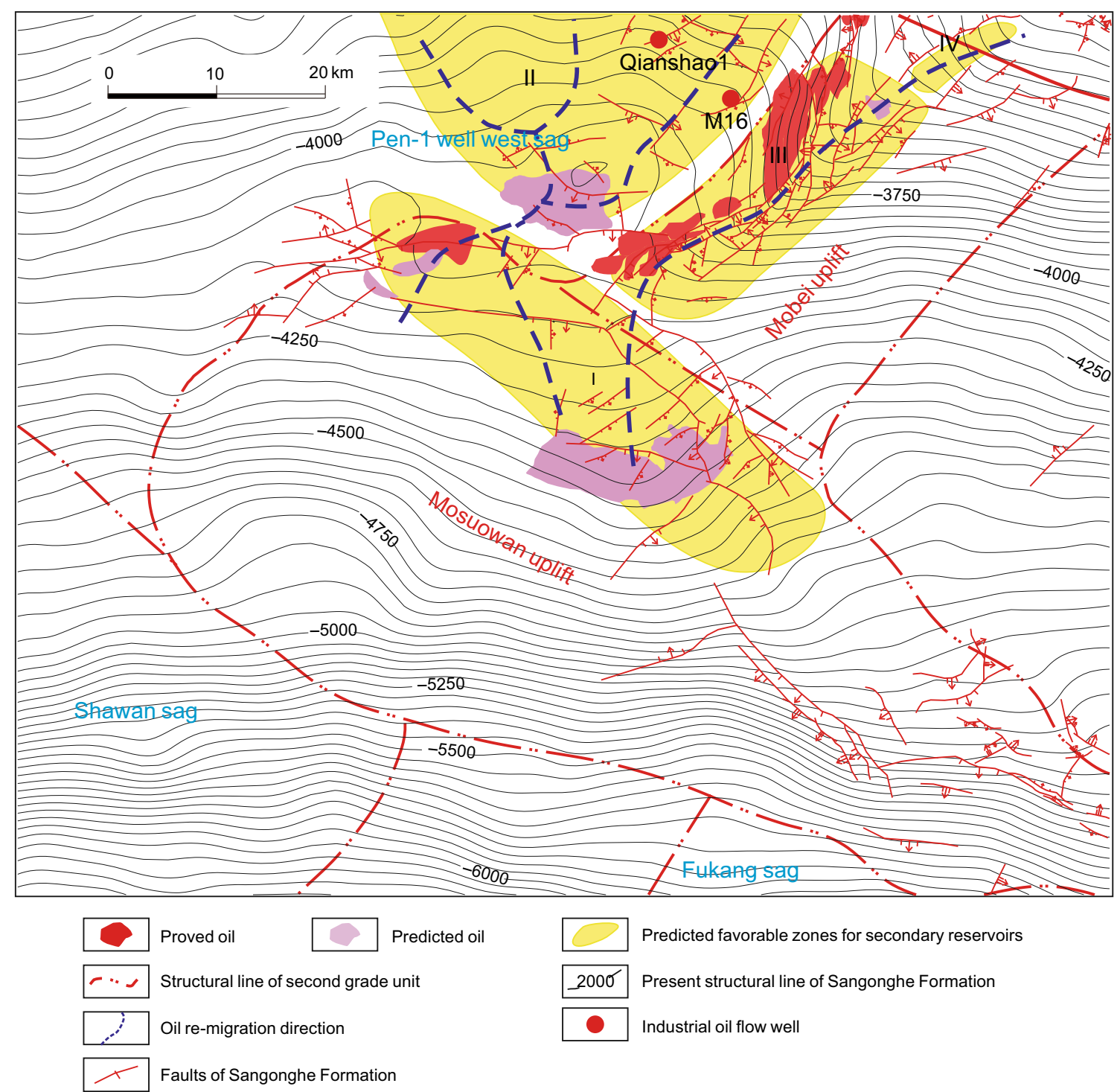

Fig. 13 Predicted favorable zones for secondary reservoirs. I Favorable zones for low-relief anticlinal reservoirs; II, IV Favorable zones for lithologic pinch-out reservoirs; III Favorable zones for fault block reservoirs

\section{Conclusions}

In the Cretaceous, which was the primary hydrocarbon accumulation period, paleo oil and gas pools were formed in the Mosuowan-Mobei area due to the good configuration of source rock, structure, sand body and fault. These largescale paleo oil and gas pools provide a great potential for predicting secondary accumulations. In the Neogene time, tectonic tilting enabled linear adjustment of the paleo i.e., the low-relief anticlinal pools distributed along the residual low uplift belt on the northern flank of the paleoanticline, the lithologic pinch-out pools controlled by lithologic pinch-out zones in the peripheral area of the inherited paleo uplift, and the fault block pools formed as the result of barriers produced by fault zones perpendicular to the migration pathway. According to the main factors that control the secondary oil and gas pools and current structural characteristics, four secondary plays of the above 
three types have been predicted. These are (1) a low-relief structural zone on the northern flank of the Mosuowan paleo uplift; (2) the Qianshao low-relief uplift belt, (3) the northern part of the Mobei uplift that parallels the fault zone; and (4) the fault barrier belt on the western flank of the Mobei uplift.

The study above not only provides guidance for deploying the next-step exploration for secondary oil and gas pools in the hinterland of the Junggar Basin, but also has an influence on other areas. Meanwhile, the study process has proposed a method for evaluating and predicting paleo hydrocarbon pools and secondary reservoirs, which is also worth applying to other basins.

Acknowledgements This work was supported by the National Science and Technology Major Project (Grant No. 2016ZX05046-001) and the Petroleum Science Research and Technology Development Project, PetroChina (Grant No. 2016B-0301). We thank Liu Gang, Yang Fan and Yang Chun for their help in collecting samples. Special thanks should be extended to Professor Liu Keyu for his helpful guidance and discussion in QGF experiment and analysis.

Open Access This article is distributed under the terms of the Creative Commons Attribution 4.0 International License (http://creative commons.org/licenses/by/4.0/), which permits unrestricted use, distribution, and reproduction in any medium, provided you give appropriate credit to the original author(s) and the source, provide a link to the Creative Commons license, and indicate if changes were made.

\section{References}

Bird KJ, Houseknecht DW. Chapter 32 Geology and petroleum potential of the Arctic Alaska petroleum province. Geol Soc Lond Mem. 2011;35(1):485-99. https://doi.org/10.1144/m35.32.

Boreham CJ, Crick IH, Powell TG. Alternative calibration of the Methylphenanthrene Index against vitrinite reflectance: application to maturity measurements on oils and sediments. Org Geochem. 1988;12(3):289-94. https://doi.org/10.1016/01466380(88)90266-5.

Cao J, Jin Z, Hu WX, et al. Integrate GOI and composition data of oil inclusions to reconstruct petroleum charge history of gascondensate reservoirs: example from the Mosuowan area, central Junggar basin (NW China). Acta Pet Sin. 2007;23(1):137-44. https://doi.org/10.3969/j.issn.1000-0569.2007.01.017

(in
Chinese).

Dong HZ. Oil-gas source and reservoir-forming mechanism of Damoguaihe Formation in the southern Wu'erxun sag, Hailar Basin. Acta Pet Sin. 2011;32(1):62-9. https://doi.org/10.7623/ syxb201101009 (in Chinese).

Du Y, Chen J, Cui Y. Genetic mechanism and development of the unsteady Sarvak play of the Azadegan oil field, southwest of Iran. Pet Sci. 2016;13(1):34-51. https://doi.org/10.1007/s12182016-0077-6.

Feng YL, Jiang S, Wang CF. Sequence stratigraphy, sedimentary systems and petroleum plays in a low-accommodation basin: middle to upper members of the Lower Jurassic Sangonghe Formation, Central Junggar Basin, Northwestern China. J Asian Earth Sci. 2015;105:85-103. https://doi.org/10.1016/j.jseaes. 2015.03.025.
Gong S, George SC, Volk H, et al. Petroleum charge history in the Lunnan Low Uplift, Tarim Basin, China-evidence from oilbearing fluid inclusions. Org Geochem. 2007;38(8):1341-55. https://doi.org/10.1016/j.orggeochem.2007.02.014.

Han JH, Wang YM, Leng JG. Prediction of favorable zone in shallow secondary-reservoir in the north of Songliao Basin. Pet Geol Oilfield Dev Daqing. 2011;30(1):7-11. https://doi.org/10.3969/j. issn.1000-3754.2011.01.002 (in Chinese).

He DF, Chen XF, Zhang YJ, et al. Enrichment characteristics of oil and gas in Junggar basin. Acta Pet Sin. 2004;3(3):1-10. https:// doi.org/10.7623/syxb200403001 (in Chinese).

He Y, Mou ZH, Tang Y. The condition and pattern of reservoir formation at Luxi area in Junggar Basin. J Southwest Pet Univ. 2007;29(04):34-8. https://doi.org/10.3863/j.issn.1674-5086. 2007.04.008 (in Chinese).

He DF, Chen XF, Kuang J, et al. Development and genetic mechanism of Chepaizi-Mosuowan Uplift in Junggar Basin. China. Earth Sci Front. 2008;15(4):42-55. https://doi.org/10. 1016/s1872-5791(08)60038-x.

$\mathrm{Hu}$ SY, Wei YJ, Dong DZ, et al. Control of fault activity on hydrocarbon accumulation in central Junggar Basin. Acta Pet Sin. 2006;27(1):1-7. https://doi.org/10.7623/syxb200601001 (in Chinese).

Huang W. Guo CS Accumulation and distribution of the hydrocarbon reservoirs in Heidimiao oil layers of Songliao Basin. Pet Geo Oil Dev Daqing. 2014;33(6):21-5. https://doi.org/10.3969/j.issn. 1000-3754.2014.06.004 (in Chinese).

IHS Energy. Timan-Pechora Basin. 2009. http://www.IHS.com/.

Ji YL, Zhou Y, Kuang J, et al. The formation and evolution of Chepaizi-Mosuowan paleo-uplift and its control on the distributions of the sedimentary facies in the Junggar Basin. Sci China Earth Sci. 2010;53:818-31. https://doi.org/10.1007/s11430-0103068-2.

Li WT, Gao Y, Geng CY. Genetic types and geochemical characteristics of natural gases in the Jiyang depression, China. Pet Sci. 2015;12(1):81-95. https://doi.org/10.1007/s12182-014-0003-8.

Liu K, Eadington P. Quantitative fluorescence techniques for detecting residual oils and reconstructing hydrocarbon charge history. Org Geochem. 2005;36(7):1023-36. https://doi.org/10. 1016/j.orggeochem.2005.02.008.

Liu $\mathrm{K}$, Eadington $\mathrm{P}$, Middleton $\mathrm{H}$, et al. Applying quantitative fluorescence techniques to investigate petroleum charge history of sedimentary basins in Australia and Papuan New Guinea. J Pet Sci Eng. 2007;57(1):139-51. https://doi.org/10.1016/j. petrol.2005.11.019.

Liu K, Bourdet J, Zhang BD, et al. Hydrocarbon charge history of the Tazhong Ordovician reservoirs, Tarim Basin as revealed from an integrated fluid inclusion study. Pet Explor Dev. 2013;40(2):171-80. https://doi.org/10.1016/s18763804(13)60021-x.

Lu X, Liu K, Zhuo Q, et al. Palaeo-fluid evidence of the multi-stage hydrocarbon charges in Kela-2 gas field, Kuqa foreland Basin, Tarim Basin. Pet Explor Dev. 2012;39(5):574-82. https://doi. org/10.1016/s1876-3804(12)60078-0.

Ma WJ, Wang R, Wang F, et al. Application of quantitative grain fluorescence technique in restoration of hydrocarbon charging history of Jurassic reservoirs in Mosuowan swell, Junggar Basin. Xinjiang Pet Geol. 2016;37(5):524-9. https://doi.org/10.7657/ xjpg20160505 (in Chinese).

Ma WJ, Wei YZ, Zeng DL, et al. Fluid evidence of paleo-reservoir in the Mosuowan uplift, Junggar Basin. Acta Pet Sin. 2017;38(4):414-24. https://doi.org/10.7623/syxb201704005 (in Chinese).

Radke M, Welte DH, Willsch H. Maturity parameters based on aromatic hydrocarbons: influence of the organic matter type. Org 
Geochem. 1986;10(86):51-63. https://doi.org/10.1016/01466380(86)90008-2.

Sun DQ. Accumulation model and control factor of secondary lithostratigraphic reservoir in the hinterland of Junggar Basin. Res Inst Pet Explor Dev, PetroChina, 2009.

Tang Y, Kong YH, Sheng JH, et al. Controlling factors of reservoir formation in ramp-type lithostratigraphic reservoir in hinterland of Junggar basin. Acta Sedimentol Sin. 2009;27(3):567-72 (in Chinese). https://doi.org/10.14027/j.cnki.cjxb.2009.03.012.

Tao SZ, Li JZ, Liu SB, et al. Formation condition, distribution law and exploration potential of far-source secondary oil and gas reservoir. J China Univ Min Technol. 2017;46(04):1-16. https:// doi.org/10.13247/j.cnki.jcumt.000618 (in Chinese).

Underdown R, Redfern J. Petroleum generation and migration in the Ghadames Basin, North Africa: a two-dimensional basin-modeling study. AAPG Bull. 2008;92(1):53-76. https://doi.org/10. 1306/08130706032.

Wang FY, Shi YL, Zeng HS, et al. To identify paleo-oil reservoir and to constrain petroleum charging model using the abundance of oil inclusions. Bull Miner Pet Geochem. 2006;25(1):12-8. https://doi.org/10.3969/j.issn.1007-2802.2006.01.002

(in Chinese).

Wang TT, Yang SY, Duan SS, et al. Multi-stage primary and secondary hydrocarbon migration and accumulation in lacustrine Jurassic petroleum systems in the northern Qaidam Basin, NW China. Mar Pet Geol. 2015;62:90-101. https://doi.org/10.1016/j. marpetgeo.2015.01.015.

Wei YZ, Yang F, Lu S, et al. Pre-Cretaceous Palaeogeomorphologic feature and its significance to oil and gas in hinterland area of Junggar Basin. Energy Explor Exploit. 2014;32(1):227-42. https://doi.org/10.1260/0144-5987.32.1.227.

Xiang BL, Li ET, Gao XW, et al. Petroleum generation kinetics for Permian lacustrine source rocks in the Junggar Basin, NW China. Org Geochem. 2016;98:1-17. https://doi.org/10.1016/j. orggeochem.2016.05.003.
Xie XM, Cao J, Hu WX, et al. Origin and application of GOI data of oil inclusions in structurally complex basins: a case study in the Mosuowan area of the Junggar Basin (NW China). Acta Geol Sin. 2007;81(6):834-42. https://doi.org/10.3321/j.issn:00015717.2007.06.013 (in Chinese)

$\mathrm{Xu} \mathrm{S}$, Hao F, Xu CG, et al. Oil migration through preferential petroleum migration pathway (PPMP) and polycyclic faults: a case study from the Shijiutuo Uplift, Bohai Bay basin, China. Mar Pet Geol. 2016;73:539-53. https://doi.org/10.1016/j.marpet geo.2016.03.025.

Ye SJ, Zhu HQ, Li R, et al. Tracing natural gas migration by integrating organic and inorganic geochemical data: a case study of the Jurassic gas fields in western Sichuan Basin, SW China. Pet Explor Dev. 2017;44(4):582-94. https://doi.org/10.1016/ s1876-3804(17)30067-8.

Zhang SW, Wang YS, Shi DS, et al. Meshwork-carpet type oil and gas pool-forming system-taking Neogene of Jiyang depression as an example. Pet Explor Dev. 2003;30(1):1-10. https://doi.org/ 10.3321/j.issn:1000-0747.2003.01.001 (in Chinese).

Zhang YJ, Cao J, Hu WX. Timing of petroleum accumulation and the division of reservoir-forming assemblages, Junggar Basin, NW China. Pet Explor Dev. 2010;37(3):257-62. https://doi.org/10. 1016/s1876-3804(10)60031-6.

Zhu GY, Su J, Yang HJ, et al. Formation mechanisms of secondary hydrocarbon pools in the Triassic reservoirs in the northern Tarim Basin. Mar Pet Geol. 2013a;46:51-66. https://doi.org/10. 1016/j.marpetgeo.2013.06.006.

Zhu GY, Zhang SC, Su J, et al. Secondary accumulation of hydrocarbons in Carboniferous reservoirs in the northern Tarim Basin, China. J Pet Sci Eng. 2013b;102:10-26. https://doi.org/ 10.1016/j.petrol.2013.01.005.

Zou HY, Zhang YC, Liu JZ, et al. Evolution of the moxizhuang oil field, Central Junggar Basin, Northwest China. J Earth Sci. 2008;19(3):242-51. https://doi.org/10.1016/s10020705(08)60043-6. 